\begin{tabular}{|r|c|c|}
\hline \multicolumn{1}{|c|}{ Received: September 2017} & Accepted: January 2018 & Published: April 2018 \\
\hline \hline & Article DOI: $\underline{\text { http://dx.doi.org/10.24903/sj.v3i1.139 }}$ \\
\hline
\end{tabular}

\title{
Variety Of Second Singular Pronouns In Serawai Language
}

\author{
Nopriansah \\ University of Dehasen Bengkulu \\ nopriansahad@gmail.com
}

\begin{abstract}
This study focuses on the use of various second singular pronouns in Serawai language spoken in the village of Maras, the District of Seluma, Bengkulu Province, Indonesia. It aimed to provide a complete and valid description of the form, meaning, and context of various second singular pronouns in the language. The data were collected by using observational methods. The techniques applied in collecting the data were interview, reading some supporting literatures, recording the language production, and taking field notes. In analyzing the collected data, the researcher used the referential identity and distributional methods. While dividing the key factors, equalizing, differentiating, equalizing the main points, segmenting immediate constituents, substituting, and deleting are techniques applied in analyzing the data. By analyzing the forms, meanings, and functions of the objects, it was concluded that the two lexicons found were a variety of second singular pronouns in Serawai language. Whereas, the selection of using one of the variations was closely related to the social context of the speaker and the speech partner. The result of this study is expected to be useful for the development of linguistics.
\end{abstract}

Keywords: form, meaning, variety, second singular pronouns, serawai language 


\section{INTRODUCTION}

Serawai language is one of the local languages in Bengkulu Province, Indonesia, that has a variety of pronouns to refer to one same speech partner. This language use areas include the (sub) districts of Seluma, Talo, Manna, Pino, Seginim, and Kaur. Until now the language is still alive and kept by its speaker community as a communication tool (Suryadi, Supadi, Elfrida, \& Suwarno, 2002). The role of norms that regulate the synergy and harmony of communication as a relationship in the social life of Serawai society is decisive. The rules are mostly unwritten. The social agreement to use a variety of pronouns to refer to the same speech partners is established and taught informally from generation to generation, especially between young and old generations where young people are required to be able to choose the exact singular pronoun for the second individual that is older than them. The choice of the speech variation is determined by the context or social aspect of the speaker and the speech partner. The diversity of choice is an interesting linguistic phenomenon to be studied.

Some other studies on Serawai language by Aliana (1982), Aliana, Zakaria, \& Yusuf, (1985), and Arifin, Aliana, Mairu, Gaffar, \& Kusmiarti (1986) discuss phenomena at the level of phonological, morphological and syntactic structures as well as on the reduplication of the language by Suryadi, Supadi, Elfrida, \& Suwarno (2002). All of the studies focus on the objects that this study refers to for some data and analysis.

This study focuses on the choice of various second singular pronouns in Serawai language spoken in the village of Maras, Seluma District. The analysis of the chosen variations was done mainly based on Sociolinguistics. Based on the study, the choice of various second singular pronouns could be adapted according to social context or social status such as the status and social class of the speaker or speech partner. The same condition prevails also in Serawai language which has various second singular pronouns that the use is largely determined by who the speaker and his or her speech partners. These choices are the variety of lexicon speech (Chaika, 1982). This study aimed to provide a complete and valid description of the form, meaning, and context of the use of various second singular pronouns in Serawai language. Thus, the expected result is a description of the aspect.

This research refers to general linguistic and sociolinguistic theories that relate to the forms, meanings, functions, and context of speech. The theories were put forward by Chaika (1982), Lyons \{as cited in Djajasudarma (2009)\}, Hymes and Poedjosoedarmo \{as cited in Revita (2013)\}, as well as various other views that have correlation with this research. In studying the structure/form of language, one will expose the terms of phonemes, morphemes, 
lexemes, phrases, clauses, and sentences. Chaika (1982) said that the pronouns in some languages of the world can be lexicons or phrases. This limitation also applies to the variety of second singular pronouns in Serawai language. The pronouns are used by choosing correctly one of them that is suitable for any speech partner based on some factors.

Hymes \{as cited in Revita (2013)\} suggested that there are several factors that must be considered when speaking to someone. These factors are introduced by Hymes in a concept known as SPEAKING. Hymes developed the concept to promote the analysis of discourse as a series of speech events and speech acts within a cultural context. The SPEAKING concept stands for Setting and Scene, Participants, Ends, Act Sequence, Key, Instrumentalities, Norm and Genre.

Setting refers to the time and place of a speech act and, in general, to the physical circumstances. A school might be a setting for a friendship story. Whereas, Scene is the "psychological setting" or "cultural definition" of a scene, including characteristics such as range of formality and sense of play or seriousness. The friendship story may be told at a school reunion. At times, the former students would be happy and playful.

Participants are the speakers and audience. At the school reunion, a former student might tell a story to the teacher, but the junior, although not addressed, might also hear the conversation. In this situation, the former student, the teacher, and the junior are the participants. The speakers are the former student and the teacher. Whereas, the audience are the junior.

Ends are the purposes, goals, and outcomes. The former student may tell a story about a goal to motivate the junior. In this situation, whether the former student realizes or not about his/her story effects to the audience, he/she must have a purpose eventhough it is a mere talking. In this case, consciousness matters.

Act sequence means the form and order of the event. The former student's story might begin as a response to a question from the teacher. The story's plot and development would have a sequence structured by the student. Possibly there would be an interruption during the telling. Finally, the group might applaud and have some brunch. All of those actions sequencially happen and develop an event.

Key is the cues that establish the "tone, manner, or spirit" of the speech act. The former student might imitate a teacher's voice and gestures in a playful way, or he/she might address the group in a serious voice. The cue the former student chooses may be different from one speech act to another. 
Instrumentalities are the forms and styles of speech. The former student might speak in a casual word with many dialect features or might use a more formal one. Here, the instrumentalities are definitely not the same as the key. Forms and styles of speech are the words spoken by the student. Meanwhile, the way how the words are spoken is the key.

Norms are the social rules governing the event and the participants' actions and reaction. In a playful story by the student, the norms might allow many audience interruptions and collaboration. A serious, formal story by the student might call for attention to him/her.

Meanwhile, genre is the kind of speech act or event. The student might tell a character anecdote about a teacher for entertainment. The last factor depends on the others. Genre can be determined by seeing the setting, scene, participants, end, acts, key, instrumentalities, and norm.

The concept of SPEAKING were also used by the researcher to analyze the object of the study. It is revealed in the term of context for any speech act and speech event. The results of this study are expected to develop science and knowledges especially in sociolinguistic field of Serawai language. This study can also be used as the additional reference for researches on the relations and comparisons of regional languages. Thus, the results of this research can be useful for the development of Linguistics in Indonesia.

\section{METHODOLOGY}

This research is a descriptive study. The data were collected by using observational methods. The techniques applied in collecting the data were interview, reading some supporting literatures, recording the language production, and taking field notes. In analyzing the collected data, the researcher used the referential identity and distributional methods. While dividing the key factors, equalizing, differentiating, equalizing the main points, segmenting immediate constituents, substituting, and deleting are techniques applied in analyzing the data. Sudaryanto (1993) said that to divide the lingual unit of the word into various types then the difference of referents must be known first; and to know the difference of the referent, the mental power of the researcher must be used. In this study the referent is the pronouns in the Serawai language which has a variety of speech that can sociolinguistically be chosen based on the status and social class of speakers or partners said. 


\section{FINDINGS AND DISCUSSION}

As defined by Kridalaksana (2008) that pronoun is a word that replaces the nominal noun or phrase, the object of this study replaces the nominal noun also. When viewed from the function, it can be said that pronouns in Serawai language occupy positions generally occupied by nouns, such as subject, object, and in certain sentence as well as predicate. Another feature that the pronouns have is that the references may be changeable because they depend on who is the speaker/author, who is the listener/reader, or who/what is being discussed.

There were three kinds of pronouns in Serawai language, namely (1) personal pronouns, (2) pronouns of pointers, and (3) pronouns of questioners. Personal Pronouns are pronouns used to refer to people. The pronoun may refer to the one's own self (pronoun of the first person), i.e. $\langle a k u\rangle,\langle k a m i\rangle$, and $\langle$ kitau $\rangle$, refer to the person to whom the second person speaks, i.e. <diri> 'you, the old' and <kaba> 'you, the young', or refer to the person in question (third person pronoun), i.e. $\langle$ diau $\rangle,\langle$ ble $\rangle,\langle$ kapo $\rangle$.

As mentioned above, the pronoun of the second singular person has two forms, namely < diri> 'you, the old' and <kaba> 'you, the young'. In their daily use, these two singular pronouns can be chosen according to the context. These pronoun choices are the variety of lexicon speech. The ability of a person to determine which lexicon he or she will use when referring to a speech partner will depend on a context not inseparable from the social aspect including the status and social class of the speaker or the speech partner.

The second singular pronouns in Serawai language are expressed in the following sample conversation:

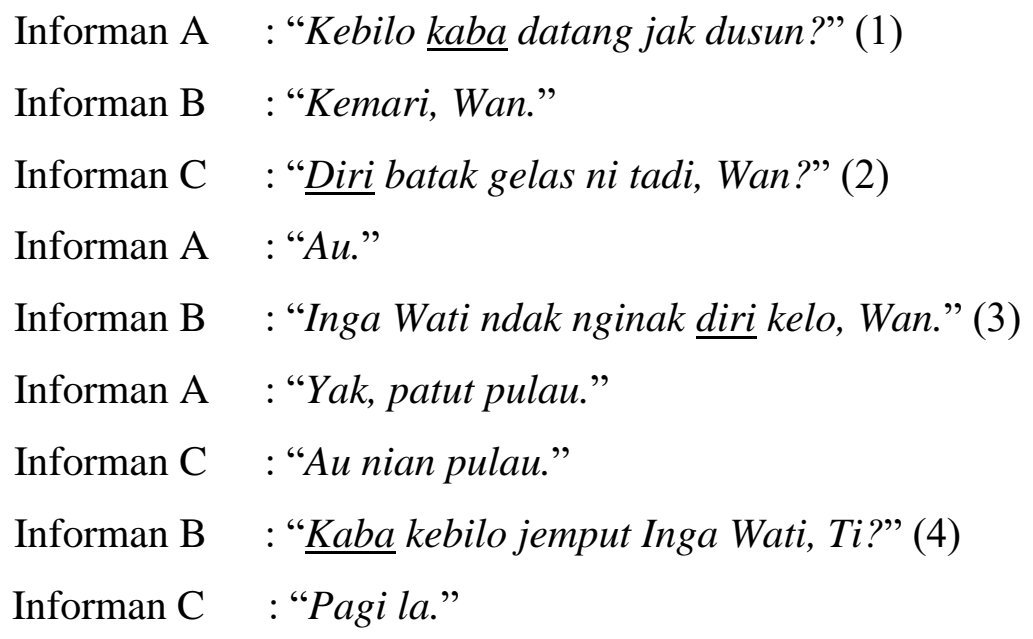


In the above conversation, the second singular pronouns are the underlined lexicons. There are two kinds of lexicon which are also the variety of second singular pronouns in the conversation, i.e. <kaba> 'you, the young' and $<$ diri $>$ 'you, the old'.

Data 1. Informant A to informant B

$$
\begin{aligned}
& \text { Informant A : "Kebilo kaba datang jak dusun?" } \\
& \text { 'When 1stSP come from village' } \\
& \text { 'When did you come from the vilage?' }
\end{aligned}
$$

\section{Context:}

A 50-year-old male (informant A) asked another 45-year-old man (informant B) about when he came from his village. Both men had a familial relationship in which informant A was the brother-in-law of the informant B. The conversation took place in $\mathrm{B} / \mathrm{C}$ 's house in the afternoon in a relaxed atmosphere.

\section{Data 4. Informant $\mathrm{B}$ to informant $\mathrm{C}$}

\section{Informant B : “ "Kaba kebilo jemput Inga Wati, Ti??"}

'1stSP when pick up sister noun-Wati, noun-Ti'

'When will you pick up sister Wati, Ti?'

\section{Context:}

A 50-year-old male (informant A) asked a 40-year-old female (informant C) about when she picked up her sister named Wati. These man and woman had a familial relationship in which informant $A$ was the brother of the informant $C$. The conversation took place in B/C's house in the afternoon in a relaxed atmosphere.

Data 2. Informant $\mathrm{C}$ to informant $\mathrm{A}$

$$
\begin{aligned}
\text { Informant C } \quad \text { : } & \text { Diri batak gelas ni tadi, Wan?" } \\
& \text { '1stSP put glass this just now Noun-Wan' } \\
& \text { 'Did you put this glass just now, Wan?' }
\end{aligned}
$$

\section{Context:}

A 40-year-old female (informant C) asked a 50-year-old male (informant A) whether she was putting a glass at a place meant by the speaker. These woman and man had a familial relationship in which informant $\mathrm{C}$ was the younger brother of the informant A. The conversation took place in B/C's house in the afternoon in a relaxed atmosphere. 
Data 3. Informant B to informant A

Informant B : "Inga Wati ndak nginak diri kelo, Wan."

'Sister Noun-Wati want see 1stSP next time Noun-Wan'

'Sister Wati wants to see you soon, Wan'

Context:

A 45-year-old male (informant B) told another 50-year-old male (informant A) about the wishes of a woman named Wati to meet with the speech partner in the future. Both men had a familial relationship in which informant B was a brother-in-law of informant $\mathrm{A}$. The conversation took place in $\mathrm{B} / \mathrm{C}$ 's house in the afternoon in a relaxed atmosphere.

Serawai language has two variations of second singular pronouns to refer to a speech partner, namely <kaba> 'you, the young' and <diri> 'you, the old'. The concept of SPEAKING was applied in analyzing the speech event where the pronouns were uttered. The explanation is shown in the following table.

\begin{tabular}{|l|l|}
\hline \multicolumn{1}{|c|}{ Factor } & \multicolumn{1}{c|}{ Explanation } \\
\hline Setting & In a house \\
\hline Participants & Informant A, B, and C \\
\hline Ends & $\begin{array}{l}\text { Informant B informed informant A about Inga Wati's } \\
\text { visiting. } \\
\text { Informant A asked informant C about when to pick up } \\
\text { Inga Wati }\end{array}$ \\
\hline Act Sequence & $\begin{array}{l}\text { Informant B came to Informant A's house, Informant } \\
\text { C interrupted their conversation, the next conversation } \\
\text { involved those three people. }\end{array}$ \\
\hline Key & In an informal situation among three relatives \\
\hline Instrumentalities & All informants used casual words/registers \\
\hline Norm & The social norm allowed any one to interrupt \\
\hline Genre & Casually informative event \\
\hline
\end{tabular}

Table 1. Factors Involved in the Choosing of the Second Singular Pronouns

Based on the table, the factors that were involved in the choosing of the second singular pronouns were considered well by the speakers.

Data 1. Informant A to informant B 


\section{Informant A : "Kebilo kaba datang jak dusun?" \\ 'When 1stSP come from village' \\ 'When did you come from the vilage?'}

\section{Context:}

A 50-year-old male (informant A) asked another 45-year-old man (informant B) about when he came from his village. Both men had a familial relationship in which informant A was the brother-in-law of the informant B. The conversation took place in $\mathrm{B} / \mathrm{C}$ 's house in the afternoon in a relaxed atmosphere.

The second singular pronoun in the above conversation is the lexicon <kaba>. The meaning of the pronoun is 'you, the young'. The choice of the second singular pronouns $<$ kaba> 'you, the young' in the above conversation is influenced by the social aspect of the speaker and the speech partner. The speaker is a man who is five years older than the speech partner. In addition, the social status of the two speakers is also different but still in a marriage bond that the informant $\mathrm{A}$ is the brother-in-law of the informant $\mathrm{B}$.

In the speech event, the informant B might not use other second singular pronouns due to the different ages and social status in the same culture. Serawai language, together with the pronouns, is used daily among the people of Serawai. The people would probably not use other pronouns than Serawai ones when they talk to each other. Thus, the pronoun of Bengkulu $<$ kau $>$ 'you, the young', for instance, might not be used in the speech event.

\section{Data 4. Informant B to informant C \\ Informant B : “Kaba kebilo jemput Inga Wati, Ti?” \\ ' 1 stSP when pick up sister noun-Wati, noun-Ti' \\ 'When will you pick up sister Wati, Ti?'}

\section{Context:}

A 50-year-old male (informant A) asked a 40-year-old female (informant C) about when she picked up her sister named Wati. These man and woman had a familial relationship in which informant $A$ was the brother of the informant $\mathrm{C}$. The conversation took place in $\mathrm{B} / \mathrm{C}$ 's house in the afternoon in a relaxed atmosphere.

The second singular pronoun form in the above conversation is the lexicon <kaba>. The meaning of the pronoun is 'you, the young'. The choice of the second singular pronouns 
$<\mathrm{kaba}>$ 'you, the young' in the above conversation is influenced by the social aspect of the speaker and the speech partner. Speaker is a man whose age is 10 years older than his speech partner. In addition, fraternal relationship also influences the selection of pronoun <kaba> where the informant $\mathrm{A}$ is the brother of the informant $\mathrm{C}$.

In the speech event, the informant B might not use other second singular pronouns due to the different ages. He might not use other pronouns than Serawai ones when he talked to informant $\mathrm{C}$. Thus, the pronoun of Bengkulunese $<\mathrm{kau}>$ 'you, the young' might not also be used in the speech event.

Data 2. Informant $\mathrm{C}$ to informant $\mathrm{A}$

Informant C : "Diri batak gelas ni tadi, Wan?"

'1stSP put glass this just now Noun-Wan'

'Did you put this glass just now, Wan?'

Context:

A 40-year-old female (informant C) asked a 50-year-old male (informant A) whether she was putting a glass at a place meant by the speaker. These woman and man had a familial relationship in which informant $\mathrm{C}$ was the younger brother of the informant A. The conversation took place in B/C's house in the afternoon in a relaxed atmosphere.

The second singular pronoun form in the above conversation is the lexicon <diri>. The meaning of the pronoun is 'you, the old'. The choice of the pronoun is influenced by the social aspect of the speaker and the speech partner. The speaker is a woman whose age is 10 years younger than her speech partner.

In the speech event, the informant $\mathrm{C}$ might not use other second singular pronouns due to the different ages. She might not use other pronouns of Serawai language than <diri> "you, the old" when she talked to Informant B. The using of pronoun $<$ kaba $>$ "you, the young' becomes impolite if it refers to the older speech partner, especially in the speech event.

Data 3. Informant B to informant A

Informant B : "Inga Wati ndak nginak diri kelo, Wan."

'Sister Noun-Wati want see 1stSP next time Noun-Wan'

'Sister Wati wants to see you soon, Wan'

Context: 
A 45-year-old male (informant B) told another 50-year-old male (informant A) about the wishes of a woman named Wati to meet with the speech partner in the future. Both men had a familial relationship in which informant B was a brother-in-law of informant $\mathrm{A}$. The conversation took place in B/C's house in the afternoon in a relaxed atmosphere.

The second singular pronoun form in the above conversation is the lexicon <diri>. The meaning of the pronoun is 'you, the old'. The choice of the pronoun is influenced by the social aspect of the speaker and the speech partner. The speaker is a man who is five years younger than his speech partner. In addition, the social status of the two speakers is also different but still within a marriage bond that the informant $\mathrm{B}$ is the brother-in-law of the informant A.

In the speech event, the informant A might not use other second singular pronouns due to the different ages and social status. He might not use other pronouns of Serawai language than < diri> 'you, the old" when he talked to Informant B. The using of pronoun $<$ kaba $>$ 'you, the young' becomes impolite if it refers to the older speech partner as well as the one who has a higher status, especially in the speech event.

Second singular pronouns <kaba> 'you, the young' is used in informal situations, such as in everyday conversations or in a state of anger. This pronoun refers to a younger person or the one who has a lower social status. While the pronoun of $<$ diri $>$ 'you, the old' is used in formal situations, such as in a meetings, or to refer to older people, the one who has higher social status or refer to the adult that is not yet known at all by the speaker.

\section{CONCLUSION}

By analyzing the forms, meanings, and functions of the second singular pronouns in Serawai language, it is concluded that the two variations of the pronouns have the same form, i.e. lexicon. The second singular pronoun of <kaba> means 'you, the young' and the one of <diri> means 'you, the old'. The selection of one of the pronouns in Serawai language is closely related to the social context of the speaker and the speech partner. Pronoun <kaba> is used by speakers who have higher social status or class or older age to a speech partner who has lower social status or class or younger age. The pronoun can also be used by speakers and speech partners who have the same or relatively same age, for example between close friends. The situation of the usage of pronoun <kaba> may be informal as in daily conversation or when the speaker is angry or underestimates the spech partner. 
Meanwhile, the pronoun of < diri> is used by speakers who have lower social status or class or younger age to partners who have higher social/class status or older age. The pronouns can also be used by speakers and speech partners who have the same or relatively same age but have not known each other. The situation of using pronoun <diri> may be informal as in everyday or formal conversations. Such as during traditional ceremonies or village meetings.

This study dealt only with the form, meaning, and context of the use of second singular pronouns in Serawai. Thus, it is necessary to conduct further researches such as relating to the internal function, value or link of pronouns of second singular person in Serawai language with verbs and so forth. 


\section{BIBLIOGRAPHY}

Aliana, Z. A. (1982). Sistem Kata Kerja Bahasa Serawai. (Departemen Pendidikan dan Kebudayaan, Ed.). Jakarta: Pusat Pembinaan dan Pengembangan Bahasa.

Aliana, Z. A., Zakaria, A. R., \& Yusuf, H. (1985). Kamus Bahasa Serawai-Indonesia. (Departemen Pendidikan dan Kebudayaan, Ed.). Palembang: Pusat Pembinaan dan Pengembangan Bahasa.

Arifin, S. S., Aliana, Z. A., Mairu, T., Gaffar, Z. A., \& Kusmiarti. (1986). Morfo-Sintaksis Bahasa Serawai. (Departemen Pendidikan dan Kebudayaan, Ed.). Palembang: Pusat Pembinaan dan Pengembangan Bahasa.

Chaika, E. (1982). Language: The Social Mirror (2nd ed.). Rowley, Massachusetts: Newbury House.

Djajasudarma, T. F. (2009). Semantik 1: Makna Leksikal dan Gramatikal. Bandung: PT Refika Aditama.

Kridalaksana, H. (2008). Kamus Linguistik. Jakarta: PT Gramedia Pustaka Utama.

Revita, I. (2013). Pragmatik: Kajian Tindak Tutur Permintaan Lintas Bahasa. Padang: Fakultas Ilmu Budaya, Universitas Andalas.

Sudaryanto. (1993). Metode dan Aneka Teknik Analisis Bahasa: Pengantar Penelitian Wahana Kebudayaan Secara Linguistis. Yogyakarta: Duta Wacana University Press.

Suryadi, Supadi, Elfrida, \& Suwarno, B. (2002). Sistem Reduplikasi Bahasa Serawai. (Pusat Bahasa, Ed.). Jakarta: Departemen Pendidikan Nasional. 